\title{
Hubungan Fungsi Manajemen Kepala Ruang dengan Motivasi Perawat dalam Melakukan Discharge Planning
}

\author{
Tazkia Rahman ${ }^{1 *}$, Endang Pertiwiwati ${ }^{2}$, Herry Setiawan ${ }^{3}$ \\ ${ }^{1,2,3}$ Program Studi Ilmu Keperawatan, Fakultas Kedokteran, Universitas Lambung \\ Mangkurat, Banjarbaru, Indonesia \\ *tazkiarahman04@gmail.com
}

\begin{abstract}
The function head of the room is a first line nursing manager who has the functions of planning, organizing, directing and supervising. Motivation is a problem for nurses in achieving and improving the quality of nursing services, especially on discharge planning. The phenomenon found in RS Kota X was the function of the head of the room management has not been carried out to the maximum and the motivation of the implementing nurse in discharge planning is still not optimal. The purpose of this research is to analyze the relationship between management function of the head of the room with motivation of nurses in discharge planning at RS Kota X. The study design was cross sectional with proportional stratified random sampling and data collection techniques carried out on 92 respondent nurses in RS Kota X from September 13, 2018 till February 28, 2019. The research instrument used a management function and motivation of nurses in discharge planning questionnaire. The results of the study was $60.9 \%$ poor and the motivation of nurses in discharge planning was $67,4 \%$ moderate. The relationship between the management function of the head of the room with the motivation of nurses in carrying out discharge planning in RS Kota $X$ with a $p$ value of $0.009<0.05$. The function of good head of the room management can increase motivation in discharge planning.
\end{abstract}

Keyword: discharge planning, management functions, head nurse, motivation

\begin{abstract}
Abstrak
Fungsi manajemen kepala ruang merupakan manajer keperawatan lini pertama yang mempunyai fungsi perencanaan, pengorganisasian, pengarahan dan pengawasan. Motivasi merupakan masalah bagi perawat dalam mencapai dan meningkatkan mutu pelayanan keperawatan khususnya pada discharge planning. Fenomena yang diperoleh di RS Kota X, fungsi manajemen kepala ruang tidak diterapkan secara maksimal serta motivasi perawat pelaksana dalam melakukan discharge planning masih belum optimal. Tujuan dari penelitian ini adalah untuk menganalisis hubungan fungsi manajemen dengan motivasi perawat dalam melakukan discharge planning pada RS Kota X. Desain pada penelitian ini menggunakan cross sectional dengan teknik pengambilan data proporsional stratified random sampling yang dilakukan kepada 92 responden perawat pelaksana di RS Kota X. Instrumen penelitian menggunakan kuesioner fungsi manajemen dan motivasi dalam discharge planning. Hasil penelitian ini menunjukkan bahwa fungsi manajemen kepala ruang 60,9\% kurang baik sedangkan motivasi perawat dalam melakukan discharge planning didapatkan sebesar $67,4 \%$. Hubungan antara fungsi manajemen kepala ruang dengan motivasi perawat dalam melakukan discharge planning di RS Kota X dengan nilai $p$ value $0,009<0,05$. Fungsi manajemen kepala ruang yang baik dapat meningkatkan motivasi dalam melakukan discharge planning.
\end{abstract}

Kata kunci: discharge planning, fungsi manajemen, kepala ruang, motivasi

Jurnal Keperawatan Raflesia, Volume 2 Nomor 2, November 2020

ISSN: (p) 2656-6222, (e) 2657-1595 DOI 10.33088/jkr.v2i2.510

Available online: https://jurnal.poltekkes-kemenkes-bengkulu.ac.id/index.php/jkr 


\section{PENDAHULUAN}

Kepala ruangan merupakan pengelola keperawatan yang terlibat langsung dalam kegiatan pelayanan kesehatan bagi pasien untuk meningkatkan efektifitas dan efisiensi pelayanan keperawatan yang berkualitas. Oleh karena itu, kepala ruangan harus melakukan fungsi manajemen dalam keperawatan untuk mencapai tujuan organisasi (Anwar, 2016).

Manajer keperawatan memiliki tanggung jawab untuk menyelesaikan masalah perawatan kesehatan seperti hal-hal yang dapat menyebabkan penyakit, struktur organisasi, manajemen perawatan, dan komunikasi antar individu, distribusi peralatan dan staff (Rizal, 2016). Kepala ruang adalah manajer keperawatan tingkat lini pertama atau front line yang bertanggung jawab untuk mengelola staff perawat (Murray \& DiCroce, 2003). Sedangkan bagi perawat ruang rawat inap, kepala ruangan merupakan pemimpin yang dapat menggerakkan perawat untuk melaksanakan asuhan keperawatan dengan baik. Kepala ruangan harus memiliki keterampilan agar dapat mengelola pelayanan secara efektif dalam manajemen guna mendukung pelayanan asuhan keperawatan (Marquis dan Huston 2010).

Kepala ruangan mempunyai fungsi manajemen meliputi fungsi perencanaan, pengorganisasian, pengarahan dan pengawasan (Rizal, 2016). Fungsi manajemen dalam perencanaan, pengorganisasian, pengarahan serta pengawasan merupakan fungsi manajemen yang bersifat universal dan mencakup semua aspek proses manajemen. Beberapa ahli menyarankan bahwa ada tanggung jawab manajemen tambahan, tetapi tambahan ini sudah termasuk dalam empat kegiatan manajemen tersebut (Rizal, 2016). Berdasarkan penelitian tentang hubungan fungsi manajemen kepala ruang terkait dengan motivasi perawat di ruang rawat inap Rumah Sakit Umum Daerah Undata Palu diperoleh hasil penelitian menunjukkan bahwa kinerja kepala ruangan dalam fungsi penataan tergolong kurang baik sebanyak 53,7\%, fungsi pengorganisasian kepala ruangan dianggap kurang baik hingga 52,3\%, fungsi pengarahan kepala ruangan dianggap rendah $(50,3 \%)$, dan kinerja kepala ruangan dalam pengawasan baik $(55,7 \%)$ (Parmin, 2009).

Fungsi manajemen yang dominan dan terpenting adalah fungsi pengarahan pada proses manajemen. Fungsi pengarahan itu meliputi komunikasi, delegasi, supervisi, manajemen konflik, serta motivasi (Lestari, 2017). Pengarahan dapat menghasilkan kondisi kerja yang bagus. Selain itu, efektifitas kinerja karyawan dapat ditingkatkan melalui kepemimpinan dengan memberikan arahan yaitu bimbingan dan motivasi kepada karyawan. Pemberian intruksi yang konsisten oleh manajer memiliki efek menciptakan komunikasi yang efektif sehingga meningkatkan motivasi perawat pelaksana dalam melakukan perencanaan pemulangan (Parmin 2009). Motivasi merupakan masalah yang sangat 
penting terutama bagi perawat dalam mencapai serta meningkatkan kualitas layanan perawatan. Jika kepala ruangan dapat mengerjakan motivasi pada perawat pelaksana maka keberhasilan kepala ruangan terlihat efektif untuk menggerakan orang lain. Motivasi dibedakan menjadi dua menurut teori Herberg yaitu motivasi instrinsik dan motivasi ekstrinsik. Motivasi yang berasal dari orang tersebut disebut motivasi intrinsik, adapun motivasi yang berada di luar orang tersebut seperti peran pemimpin atau kepala ruangan disebut motivasi ekstrinsik (Lestari, 2017).

Berdasarkan hasil penelitian terkait motivasi dan rencana pemulangan pada perawat di ruang bangsal Rumah Sakit Santa Elisabeth Medan diketahui bahwa dari 51 orang, terdapat 30 orang $(58,8 \%)$ motivasi perawat dalam kategori baik, 20 orang $(39,2 \%)$ dalam kategori cukup dan 1 orang $(2,0 \%)$ dalam kategori kurang. Hasil penelitian ini menunjukkan bahwa faktor ekstrinsik beserta indikator hubungan kerja, gaji, status, keselamatan dan keamanan kerja, serta prosedur kerja perusahaan berpengaruh terhadap efektifitas kinerja praktisi perawat, artinya semakin baik motivasi praktisi perawat dalam melaksanakan rencana pemulangan bagi pasien maka semakin tinggi kinerjanya jika terdapat hubungan yang positif antara motivasi praktisi perawat dengan efektifitas kinerja praktisi perawat. Jika pimpinan, manajer dan pegawai memiliki motivasi yang tinggi maka akan mencapai level yang tinggi pula, dan sebaliknya jika pimpinan, manajer dan pegawai memiliki motivasi rendah maka kinerjanya juga akan rendah (Peranginangin, 2015).

Salah satu pelayanan keperawatan di ruangan rawat inap yaitu melaksanakan discharge planning. Proses perencanaan sistematis yang diselesaikan untuk pasien sebelum meninggalkan lembaga perawatan dan menjaga kelangsungan perawatan disebut perencaan pemulangan. Pasien yang tidak mendapat pengobatan sebelum dipulangkan, terutama pasien yang membutuhkan perawatan kesehatan di rumah, konseling kesehatan atau penyuluhan dan pelayanan komunitas akan kembali ke ruang gawat darurat dan kemudian kembali ke rumah. Kekambuhan pasien ini tentunya akan sangat merugikan pasien, keluarga serta rumah sakit (Limpong, 2016). Laporan hasil sistem manajemen di banyak ruang rawat inap RSUD Dr. Soetomo menunjukkan bahwa $100 \%$ perawat telah melaksanakan perencanaan pemulangan akan tetapi hanya ketika pasien akan pulang karena kurangnya akses tentang pemahaman bagaimana prosedur pelaksanaan perencanaan pemulangan dan praktisi perawat banyak melakukan pekerjaan selain perencanaan pemulangan (Agustin, 2017).

Masalah yang terkait rencana pemulangan tidak hanya di Indonesia, tetapi juga di dunia. Data dunia menunjukkan bahwa perawat di Australia sebanyak (23\%) perencanaan pemulangan tidak terlaksana. Selain itu, 
di Inggris bagian barat daya menunjukkan bahwa (34\%) perawat tidak melaksanakan rencana pemulangan pula (Graham, 2013; Morris, 2012). Sedangkan di Indonesia, yakni di kota Yogyakarta terdapat $(61 \%)$ perawat tidak melaksanakan discharge planning. Sementara, studi penelitian yang dilakukan di Bandung ditampilkan bahwa $(54 \%)$ perawat di sana tidak melaksanakan perencanaan pemulangan (Okatiranti, 2015; Zuhra, 2016). Penelitian yang dilakukan oleh Betty di Rumah Sakit Achmad Muchtar (RSAM) Bukittinggi melaporkan bahwa (38\%) responden mengatakan pelaksanaan discharge planning kurang baik. Berdasarkan beberapa hasil penelitian tersebut membuktikan bahwa pelaksanaan discharge planning belum terlaksana dengan baik dan optimal (Betty, 2013).

Berdasarkan penelitian awal peneliti diperoleh data hasil wawancara pada tanggal 15 \& 16 Oktober 2018 di ruang rawat inap RS Kota X kepada 6 orang perawat pelaksana diketahui bahwa 6 orang perawat pelaksana mengatakan kepala ruangan merencanakan kegiatan dan pertemuan, 4 dari 6 perawat pelaksana mengatakan kepala ruangan memberikan teguran pada staf yang menyalahi aturan dan 3 dari 6 perawat mengatakan kepala ruangan tidak membimbing perawat dalam pelaksanaan discharge planning dan mengevaluasi kembali tugas yang dilimpahkan pada perawat. Standar Prosedur Operasional (SPO) pelaksanaan discharge planning ada di semua ruang rawat inap, 6 dari 6 perawat pelaksana mengatakan pemberian motivasi dalam melakukan discharge planning yang diberikan kepala ruang membuat perawat melakukan discharge planning dengan baik, serta tunjangan yang diberikan membuat perawat semangat dalam melakukan discharge planning.

Wawancara yang dilakukan pada 26 Oktober 2018 di ruang rawat inap RS Kota $\mathrm{X}$ dengan kepala ruang diketahui bahwa mengatakan kepala ruangan merencanakan kegiatan, pertemuan, memberikan teguran pada staff yang menyalahi aturan, membimbing perawat dalam pelaksanaan discharge planning dan mengevaluasi kembali tugas yang dilimpahkan pada perawat. Pemberian motivasi dalam bentuk pujian diberikan kepada perawat saat pergantian shift. Standar Prosedur Operasional (SPO) pelaksanaan discharge planning ada di semua ruang rawat inap, serta kepala ruangan mengatakan melakukan discharge planning saat awal masuk sampai pasien pulang.

Berdasarkan masalah yang diuraikan maka peneliti tertarik pada penelitian terkait hubungan fungsi manajemen kepala ruang dengan motivasi perawat dalam melakukan discharge planning.

\section{METODE}

Penelitian ini menggunakan rancangan penelitian kuantitatif dengan metode cross sectional. Populasi pada penelitian ini mencakup seluruh perawat pelaksana (PP) 
yang aktif bekerja di ruang rawat inap RS Kota X, lulusan DIII sampai Ners, menjabat sebagai PNS maupun BLUD. Jumlah populasi perawat pelaksana di ruang rawat inap RS Kota X adalah 119 orang perawat.

Metode pengambilan sampel yang digunakan dalam penelitian ini yaitu proporsional stratified random sampling dengan total sampel sebanyak 92 responden. Teknik sampling yang digunakan dalam penelitian ini adalah proporsional stratified random sampling yaitu teknik pengambilan sampel acak stratifikasi proporsional digunakan bila masing-masing stratum yang ada dalam populasi tidak sama besar jumlah subjek penelitiannya (Hermawanto, 2010). Kriteria inklusi adalah perawat yang bekerja di ruang rawat inap di RS Kota $X$, bersedia menjadi responden penelitian, dan perawat ruangan minimal pendidikan DIII. Kriteria eksklusi adalah perawat yang tidak lengkap dalam pengisian kuesioner dan perawat yang tidak hadir saat penelitian karena mengundurkan diri dan cuti pada hari tersebut.

Perhitungan statistik untuk data penelitian ini menggunakan program aplikasi statistik yang terdapat dalam komputer dengan uji Chi Square. Uji yang digunakan untuk korelasi dua data ordinal dengan tabel $3 \times 2$, pada hasil yang didapatkan tidak ada perawat yang termasuk kategori tidak diterapkan sehingga tabel yang digunakan adalah $2 \times 2$. Alat yang digunakan daIam peneIitian ini adalah angket yang terdiri dari 3 bagian yang sesuai yaitu karakteristik responden, fungsi manajemen kepala ruang dan motivasi perawat dalam melakukan discharge planning. Hasil uji validitas pada variabel fungsi manajemen nilai Cronbach's alpha sebesar 0,878 (tinggi) $>\mathrm{r}$ tabel $(0,361)$. Pada variabel motivasi dalam melakukan discharge planning nilai Cronbach's alpha sebesar 0,908 (tinggi) $>\mathrm{r}$ tabel (0,361). Hasil uji realibitas pada variabel fungsi manajemen nilai Cronbach's nalpha sebesar 0,878 (tinggi). Pada variabel motivasi dalam melakukan discharge planning nilai Cronbach's alpha sebesar 0,908 (tinggi).

Penelitian dilakukan di ruang rawat inap RS Kota $\mathrm{X}$ yang sudah memperoleh surat persetujuan etik dari IRB (Institusional Review Board) Fakultas Kedokteran Universitas Lambung Mangkurat secara tertulis No. 1082/KEPK-FK UNLAM/EC/XII/2018.

\section{HASIL}

\section{Karakteristik Responden}

Tabel 1. Karakteristik Responden Berdasarkan Usia $(\mathrm{n}=92)$

\begin{tabular}{lllll}
\hline Mean & Median & $\begin{array}{l}\text { Std. } \\
\text { Deviation }\end{array}$ & Min & Max \\
\hline 31 & 30 & 6,03 & 22 & 47 \\
\hline
\end{tabular}

Tabel 1 menunjukkan data dari 92 responden didapatkan bahwa rata-rata usia praktisi perawat dalam 6 ruang rawat inap yang menjadi tempat penelitian di Rumah Sakit Kota X adalah 31 tahun, dengan rentang usia termuda yaitu 22 tahun dan usia tertua berusia 47 tahun. 
Tabel 2. Distribusi Frekuensi

Karakteristik Responden

Berdasarkan Jenis Kelamin, Lama

Kerja, Status Perkawinan dan

Pendidikan $(\mathbf{n}=92)$

\begin{tabular}{lll}
\hline Variabel & $\mathrm{f}(\mathrm{n})$ & $\%$ \\
\hline Jenis Kelamin & & \\
Laki-laki & 36 & 39,1 \\
Perempuan & 56 & 60,9 \\
\hline Lama Kerja & & \\
$\leq 3$ tahun & 48 & 52,2 \\
$>3$ tahun & 44 & 47,8 \\
\hline Status Perkawinan & & \\
Kawin & 59 & 64,1 \\
Belum kawin & 33 & 35,9 \\
\hline Pendidikan & & \\
DIII Keperawatan & 59 & 64,1 \\
S1 Keperawatan & 6 & 6,6 \\
Profesi Ners & 27 & 29,3 \\
\hline
\end{tabular}

Tabel 2 menunjukan data dari 92 responden, terdapat lebih banyak responden berjenis kelamin perempuan yaitu 56 orang atau $60,9 \%$ dibandingkan responden berjenis kelamin laki-laki yaitu 36 orang atau $39,1 \%$. Lama kerja yaitu 48 orang $(52,2 \%)$ memiliki lama kerja kurang dari sama dengan 3 tahun dan 44 orang $(47,8 \%)$ memiliki lama kerja lebih dari 3 tahun. Status perkawinan terdapat lebih banyak responden yang sudah kawin yaitu 59 orang atau $64,1 \%$ dibandingkan responden yang belum kawin yaitu 33 orang atau 35,9\%. Pendidikan terdapat 59 orang atau $64,1 \%$ yang berpendidikan DIII Keperawatan, 6 orang atau $6,6 \%$ berpendidikan S1 Keperawatan, dan 27 orang atau 29,3\% berpendidikan Profesi Ners.

\section{Fungsi Manajemen Kepala Ruang}

Tabel 6. Distribusi Frekuensi Fungsi Manajemen Kepala Ruang

\begin{tabular}{lll}
\hline Variabel & $\mathrm{f}(\mathrm{n})$ & $\%$ \\
\hline Baik & 36 & 39,1 \\
Kurang Baik & 56 & 60,9 \\
Total & 92 & $100 \%$ \\
\hline
\end{tabular}

Tabel 6 menunjukkan hasil penelitian dari 92 responden yang didapatkan bahwa 56 responden mempersepsikan fungsi manajemen kepala ruang kurang baik $(60,9 \%)$, sedangkan 36 responden menyatakan fungsi manajemen kepala ruang baik $(39,1 \%)$.

\section{Motivasi perawat dalam melakukan discharge planning}

Tabel 7. Distribusi Frekuensi Motivasi Perawat dalam Melakukan Discharge Planning

\begin{tabular}{lll}
\hline Variabel & $\mathrm{f}(\mathrm{n})$ & $\%$ \\
\hline Tinggi & 30 & 32,6 \\
Sedang & 62 & 67,4 \\
Total & 92 & $100 \%$ \\
\hline
\end{tabular}

Tabel 7 menunjukkan hasil penelitian dari 92 responden yang didapatkan menunjukkan 62 responden mempersepsikan motivasi perawat pelaksana dalam melakukan discharge planning sedang $(67,4 \%)$, sedangkan 30 responden menyatakan motivasi perawat pelaksana dalam melakukan discharge planning tinggi $(32,6 \%)$. 
Hubungan fungsi manajemen kepala ruang dengan motivasi perawat dalam melakukan discharge planning

Tabel.8. Hubungan

Fungsi Manajemen Kepala Ruang dengan motivasi perawat dalam melakukan discharge planning

\begin{tabular}{lllll}
\hline Variabel & Motivasi & $\mathrm{f}$ & $\mathrm{p}$ & $\mathrm{r}$ \\
& & $(\mathrm{n})$ & value &
\end{tabular}

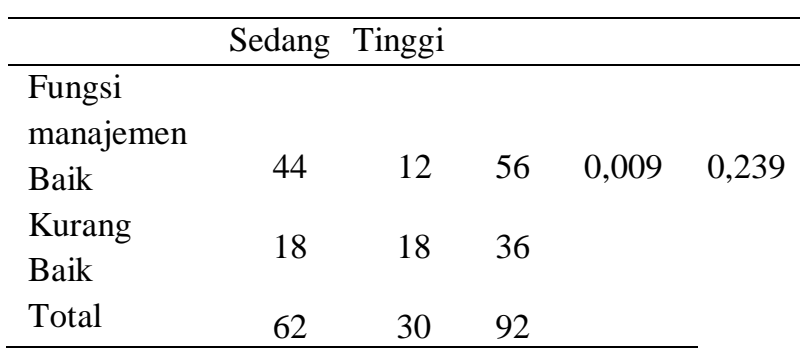

Pada tabel 8. menunjukkan bahwa hasil uji menggunakan program aplikasi statistik yang terdapat dalam komputer dengan uji Chi Square yang berjumlah sebanyak 92 responden didapatkan bahwa p-value 0,009 $<0,05$ yang artinya $\mathrm{H}_{0}$ ditolak berarti ada keterkaitan yang signifikan antara keduanya yaitu fungsi manajemen kepala ruang terhadap motivasi perawat pelaksana dalam melakukan discharge planning di RS Kota X. Koefisien relasi 0,239 menunjukkan hubungan yang rendah karena nilai $r$ termasuk pada kategori 0,20-0,399.

\section{PEMBAHASAN}

Berdasarkan hasil penelitian terdapat keterkaitan antara fungsi manajemen kepala ruang dengan motivasi perawat dalam melakukan discharge planning di RS Kota $\mathrm{X}$ dengan nilai $p$ value $0,009<0,05$. Kepala ruang dapat meningkatkan kemampuan dalam fungsi manajemen terutama perencanaan dan pengorganisasian melalui pendidikan dan pelatihan, mempertahankan dan lebih meningkatkan motivasi bagi perawat pelaksana dengan pelaksanaan SOP/SAK secara regular, rincian tugas yang jelas, dan penilaian kinerja secara obyektif khususnya pada discharge planning. Perawat pelaksana mempertahankan dan meningkatkan motivasi yang lebih baik dan diharapkan perawat pelaksana dapat mengikuti pendidikan dan pelatihan untuk meningkatkan kemampuan dan kompetensi sesuai bidangnya.

Menurut penelitian Rizal tentang keterkaitan keterampilan manajemen kepala ruangan dengan motivasi perawat dalam memberikan pelayanan keperawatan di ruang rawat RSUD Kota Semarang hasil yang didapatkan menunjukkan pengaruh signifikan antara rencana manajemen, pengorganisasian, arahan dan pengawasan kepala ruang dengan motivasi dengan $p=0,001$ (Rizal, 2016). Penelitian Sulistyawati tentang implementasi fungsi manajemen dalam pelaksanaan discharge planning menunjukkan bahwa terdapat hubungan antara pelaksanaan fungsi manajemen dan perencanaan pemulangan $(\mathrm{p}=0,001)$ dengan tingkat hubungan yang sedang (Sulistyawati, 2016).

Penelitian ini sejalan dengan pendapat Marqis dan Huston dalam Riyanti, R.D et al yang menyatakan dalam teori manajemennya untuk mendukung kinerja perawat yang baik dibutuhkan motivasi yang tinggi (Riyanti, 2015). 
Hasil penelitian lain yang mendukung penelitian ini adalah penelitian Moody, Pesut dan Tzeng dalam Riyanti, R.D et al bahwa dalam penelitiannya juga ditemukan sesuatu yang berkaitan dengan penelitian ini, terutama motivasi berpengaruh terhadap kualitas kerja dan kinerja perawat (Riyanti, 2015).

Hasil penelitian ini sejalan dengan penelitian yang dilakukan oleh Putra, Hamid \& Mustikasari dalam Sulistyawati yang menekankan bahwa terdapat pengaruh yang signifikan antara fungsi manajemen terhadap penerapan praktik keperawatan yang positif, pola hubungan dimana fungsi manajemen yang lebih baik diimplementasikan akan berdampak pada terwujudnya asuhan keperawatan dan peningkatan keterampilan keperawatan yang akan diterima oleh klien. Jika implementasinya mendukung fungsi manajemen kepemimpinan yang baik' maka perencanaan pemulangan sebagai bagian dari manajemen perawatan juga akan menjadi yang terbaik dalam implementasinya (Sulistyawati, 2016).

\section{KESIMPULAN}

Kesimpulan analisis hubungan fungsi manajemen dengan motivasi perawat dalam melakukan discharge planning pada RS Kota $X$ adalah terdapat hubungan antara fungsi manajemen kepala ruang dengan motivasi perawat dalam melakukan discharge planning di $\mathrm{RS}$ Kota $\mathrm{X}$ dengan nilai $p$ value $0,009<0,05$. Untuk peneliti yang akan melakukan penelitian yang sama pada berbagai bentuk desain terkait variabilitas fungsi manajemen ruang dan motivasi perawat dalam merencanakan pemulangan. Diharapkan ada lebih banyak penelitian dengan bentuk desain yang berbeda dan berkualitas, dapat melihat apa saja yang meningkatkan dan mengurangi motivasi perawat pelaksana dalam proses perencanaan pemulangan.

\section{DAFTAR PUSTAKA}

Agustin, R. (2017). Optimalisasi pelaksanaan discharge planning melalui pengembangan model discharge planning terintegrasi pelayanan keperawatan. Jurnal Keperawatan Muhammadiyah, 2(1), 97-10. doi:10.30651/jkm.v2i1.921

Anwar., Rochadi, K. R., Daulay, W., Yuswardi. (2016). Hubungan fungsi manajemen kepala ruang dengan penerapan patient safety culture di Rumah Sakit Umum Dr. Zainoel Abidin Banda Aceh. Idea Nursing Journal, 7(1), 26-34. Diakses dari http://jurnal.unsyiah.ac.id/INJ/articl e/view/6465/5302

Betty. (2016). Hubungan discharge planning dengan kualitas hidup pasien pasca stroke di poli neurologi RSAM Bukittinggi Tahun 2016. Jurnal Kesehatan STIKes Prima Nusantara Bukittinggi, 8(1). Diakses dari doi:http://dx.doi.org/10.35730/jk.v8i $\underline{1.289 .9332}$

Graham, J., Gallagher, R., \& Bothe, J. (2013). Nurses' discharge planning and risk assessment: behaviours, understanding and barriers. Journal of Clinical Nursing, 22, 2338-2346. doi:10.1111/jocn.12179 http://eprints.undip.ac.id/47197/ https://ejournal.bsi.ac.id/ejurnal/in dex.php/jk/article/view/149 
Hermawanto, Hery. (2010). Menyiapkan karya tulis ilmiah panduan untuk menyusun Karya Tulis Ilmiah di bidang Kesehatan. Trans Info Media: Jakarta.

Lestari, D. (2017). Hubungan motivasi kepala ruang dengan kinerja perawat di ruang dewasa RSUD Kota Yogyakarta. Skripsi, Universitas Aisyiyah, Yogyakarta. Diakses dari http://digilib.unisayogya.ac.id/396 0/1/NASKAH\%20PUBLIKASI\% 20DWI.pdf

Limpong, D., Rottie, J., Bataha, Y. (2016). Hubungan discharge planning dengan kesiapan pulang pasien penyakit jantung koroner di ruangan CVBC RSUD Prof Dr. R. D Kandou Manado. E-journal Keperawatan (e- Kp), 4(1). Diakses dari https://ejournal.unsrat.ac.id/index. $\mathrm{p}$ hp/jkp/article/view/12130

Marquis, B. L. \& Huston, C. J. (2010). Kepemimpinan dan manajemen keperawatan : teori dan aplikasi (Edisi 4). Jakarta: EGC.

Morris, J., Winfield, L \& Young, K (2012). Registered nurses' perceptions of the discharge planning process for adul patients in an acute hospital. Journal of nursing education and practice, 2(1), 28-38. doi:10.5430/jnep.v2n1p28

Murray, M. E. \& DiCroce. (2003). Leadership and Management in Nursing, Third Edition. St. Louis University.

Okatiranti. (2015). Gambaran pengetahuan dan sikap perawat dalam pelaksanaan discharge planning pada pasien Diabetes Mellitus Type II. Jurnal Ilmu Keperawatan, 3(1), 18-24. fungsi manajemen kepala ruang dengan kinerja perawat pelaksana di ruang rawat inap RSUD Undata Palu. Fakultas Ilmu Keperawatan. Tesis, Universitas Indonesia, Depok. Diakses dari http://lontar.ui.ac.id/file?file=digital/ 20284809-T\%20Parmin.pdf

Peranginangin, I. H. (2015). Hubungan motivasi dengan pelaksanaan discharge planning pada perawat $\mathrm{di}$ ruang rawat inap bagian internis tahun 2015. Diakses dari https://docplayer.info/48028637Hubungan-motivasi-denganpelaksanaan-discharge-planningpada-perawat-di-ruang-rawat-inapbagian-internis-tahun-2015.html

Riyanti, R.D., et al. (2015). Hubungan antara motivasi kerja perawat dengan pelaksanaan discharge planning di ruang rawat inap RSU PKU Muhammadiyah Bantul. Skripsi, Sekolah Tinggi Ilmu Kesehatan Aisyiyah, Yogyakarta. Diakses dari http://digilib.unisayogya.ac.id/147/

Rizal, A. A. F., Chasani, S., Warsito, B. E. (2016). Hubungan pelaksanaan fungsi manajemen kepala ruang dengan motivasi perawat pelaksana dalam memberikan layanan keperawatan di ruang rawat inap RSUD Kota Semarang. Tesis, Universitas Diponegoro, Semarang. Diakses dari http://eprints.undip.ac.id/47197/

Zuhra, P. (2016). Gambaran pelaksanaan discharge planning pasien pascaoperasi apendiktomi di RS PKU Muhammadiyah Gamping Yofyakarta. Skripsi, Universitas Aisyiyah, Yogyakarta.Diakses dari http://repository.umy.ac.id/bitstrea m/handle/123456789/7343/Naskah\% 20Publikasi.pdf?sequence $=11 \&$ isAl lowed $=y$

Parmin. (2009). Hubungan pelaksanaan 


\section{HALAMAN INI SENGAJA DI KOSONGKAN}

